УДК 342.5

\author{
В. В. Прощаєв

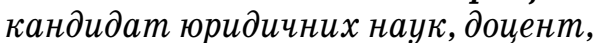 \\ доиент кафедри \\ Інституту Служби зовнішньої розвідки України
}

\title{
КОНСТИТУЦЙНЕ ЗАБЕЗПЕЧЕННЯ ДЕРЖАВНОГО НАГЛЯДУ ЗА ДІЯЛЬНІСТЮ ЗОВНІШНЬОЇ РОЗВІДКИ: ПОРІВНЯЛЬНО-ПРАВОВИЙ АНАЛІЗ
}

Порівняльний аналіз нормативно-правових актів провідних країн світу у сфері розвідувальної діяльності свідчить про намагання законодавців визначити правовими приписами питання державного нагляду за діяльністю своїх розвідувальних органів, посилаючись на конституційні положення. Але визначення його за чинним законодавством окремих держав має суттєві особливості, які свідчать про невизначеність загальних методологічних підходів до проблеми державного нагляду, його змісту, видів, форм тощо. Також існує потреба наукового осмислення й обгрунтування різниці між державним наглядом і державним контролем.

Іншими словами, проблема полягає в тому, щоб уявити, законодавці яких держав і на підставі яких конституційних положень найбільш повно та змістовно з наукових позицій визначають у законодавстві розвідку державний нагляд. Дослідження цих питань може допомогти співробітникам вітчизняних спеціальних служб у вирішенні завдань розвідувальної діяльності, а також може бути корисним для вітчизняних науковців-юристів, котрі працюють у сфері вдосконалення правової основи організації та діяльності розвідувальних органів України. Таким чином, стаття може мати як практичне, так і теоретичне значення.

Стосовно проблематики статті вітчизняних українських публікацій і видань немає. Немає відкритих наукових праць, у т.ч. і в Інтернетресурсах, з боку зарубіжних науковців.

Мета статті - на підставі порівняння законодавства деяких країн визначити й обґрунтувати методологічні підходи до вирішення проблеми правового регулювання державного нагляду за діяльністю зовнішньої розвідки, дослідити конституційні засади його здійснення, виділити ознаки спільного та відмінного між ним і державним контролем. Отже, завданнями статті є порівняльно-правовий аналіз нормативно-правових актів, насамперед конституцій держав, науковий пошук і висвітлення можливих видів, форм, напрямів і меж здійснення державного нагляду, надання пропозицій стосовно удосконалення вітчизняного законодавства у сфері розвідувальної діяльності.

Законодавці багатьох країн, розробляючи нормативно-правові акти у сфері розвідувальної діяльності, неодмінно мали визначати правовими нормами питання державного нагляду за діяльністю розвіду- вальних органів, оскільки цього, по-перше, вимагають конституційні положення, а по-друге, це є реалізацією обов'язкового принципу законотворення у правових і демократичних державах, якими себе позиціонують майже всі провідні країни світу.

Державний нагляд - функція спеціальних державних органів і їх посадових осіб у вигляді систематичного спостереження за точним і неухильним дотриманням законів, інших нормативних правових актів, що здійснюється за підвідомчими цим органам питаннями щодо не підпорядкованих їм юридичних і фізичних осіб. Такими спеціальними органами є органи прокуратури: «наглядова діяльність - це кредо прокуратури, її найголовніша функція, заради якої вона й створюється» [1, с. 51]. Це визначення науковця має більш практичну спрямованість. Але він надає й суто наукове поняття державного нагляду як автономній формі юридичної діяльності уповноважених суб'єктів, що полягає у здійсненні ними відповідно до своєї компетенції юридично значимих дій із вирішення на піднаглядних об’єктах у суворій відповідності до закону конкретних юридичних справ, які виникають у зв'язку з невиконанням або неналежним виконанням законів державними органами і посадовими особами з метою забезпечення та зміцнення законності і правопорядку, попередження та припинення правопорушень, забезпечення прав і свобод громадян та охоронюваних законом прав та інтересів суспільства і держави [1, с. 34]. Автор у наведеній цитаті під «уповноваженими суб’єктами» також мав на увазі органи прокуратури.

Отже, державний нагляд є виключною компетенцією органів прокуратури, межі повноважень яких хоча й окреслені детально в законах про прокуратуру, але не можуть перевищувати межі, визначені конституційними положеннями.

Конституції провідних країн світу визначають функціонування прокуратури (генерального прокурора та підпорядкованих йому прокурорів) за такими основними напрямами, як:

- нагляд за точним і однаковим виконанням законів, декретів, указів та інших нормативних актів міністерствами та іншими підвідомчими урядам органами, місцевими представницькими і виконавчими органами, підприємствами, організаціями й установами, громадськими об'єднаннями, посадовими особами та громадянами; 
- нагляд за виконанням законів під час розслідування злочинів, відповідністю закону судових рішень у цивільних, кримінальних справах і справах про адміністративні правопорушення;

- попереднє слідство (в окремих випадках, передбачених законом) і підтримка державного обвинувачення в судах [2].

У законодавстві різних країн межі повноважень прокуратури щодо нагляду за діяльністю розвідки визначено по-різному із суттєвими відмінностями, але неодмінно у рамках конституційних положень. Так, відповідно до Закону Грузії «Про Службу розвідки Грузії» нагляд за законністю діяльності Служби здійснює генеральний прокурор і визначений ним окремий прокуpop [3, ст. 28], але «службовий нагляд» здійснює прем'єр-міністр Грузії [3, ст. 26]. Натомість у Законі Грузії «Про розвідувальну діяльність» взагалі не йдеться про прокурорський нагляд, а тільки про «службовий нагляд за функціонуванням системи розвідки» з боку прем'єр-міністра [4, ст. 15]. У Законі Республіки Казахстан «Про зовнішню розвідку» читаємо: «Вищий нагляд за точним i однаковим застосуванням нормативних правових актів про зовнішню розвідку на території Республіки Казахстан здійснюють Генеральний Прокурор Республіки Казахстан і уповноважені ним прокурори» [5, ст. 21]. Отже, не просто нагляд, а «вищий нагляд»! У Законі Естонської Республіки «Про служби безпеки» нагляду присвячено цілий розділ, але в ньому фактично йдеться не про прокурорський нагляд, а про парламентський контроль [6, розд. 5].

Необхідно зазначити, що в законодавстві про діяльність розвідки всіх країн у статтях про прокурорський нагляд обов'язково міститься припис такого змісту: відомості про осіб, котрі конфіденційно співробітничають або співробітничали із розвідкою, а також методи, тактика й організація добування розвідувальної інформації не входять до предмету прокурорського нагляду.

Оскільки розвідувальні органи належать до державних органів, то щодо них здійснюється не тільки прокурорський, але й адміністративний нагляд.

Адміністративний нагляд, який здійснюється, наприклад, у Російській Федерації спеціальними федеральними наглядами (Федеральною службою з нагляду в сфері захисту прав споживачів і благополуччя людини, Федеральною службою з нагляду у сфері охорони здоров'я і соціального розвитку, Федеральною службою з нагляду у сфері освіти і науки, Федеральною службою з нагляду у сфері природокористування тощо) та державними інспекціями (Державною інспекцією безпеки дорожнього руху МВС Росії, Державним протипожежним наглядом МНС Росії та ін.), цілком зрозуміло, що він не застосовується до функціонування розвідувальних органів у суто розвідувальній діяльності. Тобто безпосередньо розвідувальна діяльність не входить до предмету адміністративного нагляду.

Наглядова діяльність прокуратури у сфері державного управління розвідувальними структурами здійснюється за такими напрямами, як:

1) нагляд за виконанням законів органами розвідки та їх посадовими особами, а також за відповідністю правових актів, що ними видаються, положенням чинного законодавства;

2) нагляд за дотриманням розвідувальними органами та їх посадовими особами під час проведення розвідувальної та оперативно-розшукової діяльності принципу законності, конституційних прав і свобод громадян.

Реагування представників прокуратури на порушення законності може здійснюватися у таких формах:

- протесту прокурора (наприклад, на видання розвідувальним органом або його керівником нормативно-правового акта, який суперечить чинному законодавству);

- подання прокурора (наприклад, про усунення наявних або виявлених порушень закону);

- постанови прокурора (наприклад, у разі порушення або невиконання закону посадовою особою прокурор виносить умотивовану постанову про порушення кримінальної справи або провадження про адміністративне правопорушення);

- застереження (попередження) прокурора про неприпустимість порушення закону (наприклад, з метою попередження правопорушень і за наявності відомостей про злочин, що готується, оголошується в письмовій формі попередження про неприпустимість порушення закону).

Таким чином, сутність державного нагляду за діяльністю розвідки полягає в забезпеченні законності та правопорядку шляхом виявлення й усунення порушень закону з боку співробітників розвідувальних органів, а також у їх попередженні. Зліст нагляду становить заснована на законі діяльність спеціально уповноважених суб'єктів органів прокуратури в особі генерального прокурора та визначених ним прокурорів, яка спрямована на попередження, виявлення та припинення порушень законів з метою забезпечення верховенства закону, конституційних прав і свобод громадян та охоронюваних законом інтересів суспільства і держави.

Якщо проаналізувати законодавство різних країн, то можна стверджувати про відсутність повного та детального визначення питань прокурорського нагляду за діяльністю розвідувальних органів. Зазвичай визначення його обмежується лише декількома загальними формулюваннями. Так, стосовно прокурорського нагляду в Законі Російської Федерації «Про зовнішню розвідку» визначено лише такі два моменти: 
1) нагляд за виконанням органами зовнішньої розвідки федеральних законів здійснюють Генеральний прокурор РФ і уповноважені ним прокурори;

2) відомості про осіб, котрі надають (надавали) органам зовнішньої розвідки конфіденційне сприяння, а також про організацію, про методи і засоби здійснення діяльності органів зовнішньої розвідки до предмету прокурорського нагляду не входять [7, ст. 26].

У нормативно-правових актах Республіки Білорусь питанням прокурорського нагляду за діяльністю розвідувальних служб також приділено дуже мало уваги. Так, в Указі Президента РБ «Про питання зовнішньої розвідки» [8] немає жодного слова про нагляд. У Законі РБ «Про органи державної безпеки Республіки Білорусь» [9] про прокурорський нагляд йдеться в загальних формулюваннях, а саме: нагляд за точним і однаковим виконанням органами державної безпеки законодавства РБ здійснюють Генеральний прокурор РБ і підлеглі йому прокурори в межах своєї компетенції [9, ст. 41].

Більш того, і в Законі РФ «Про зовнішню розвідку» [7], і в Законі РБ «Про органи державної безпеки Республіки Білорусь» [9] питання прокурорського нагляду за діяльністю розвідки визначено у тих же самих статтях, що і контроль. Тобто і білоруський, і російський законодавці не бачать суттєвої різниці між контролем і наглядом, тому i визначають ї загальними формулюваннями в одній статті.

Розглядаючи в науковому аспекті питання контролю $і$ нагляду за діяльністю розвідувальних органів, можна помітити, що $і$ в контролі, $i$ в наглядi є багато ознак, за якими вони збігаються.

По-перше, збігаються ознаки за правовим статусом органів контролю і нагляду, а саме:

- відсутність організаційної підпорядкованості між собою й об’єктами (суб'єктами) контролю та нагляду;

- наявність спільного спеціального об'єкту контролю і нагляду, до якого належать нормативно-правові акти, що містять вимоги, стандарти, приписи обов'язкової поведінки;

- мають певні права щодо застосування заходів примусу, якщо виявлено порушення з боку керівництва і посадових осіб розвідувальних органів, їх співробітників, працівників.

По-друге, збігаються ознаки за самим характерол діяльності органів контролю і нагляду. Контролюючі й наглядові органи:

- керуються законом і домагаються від органів розвідки виконання закону;

- мають однакову кінцеву мету - забезпечення дотримання та захисту прав і свобод людини та громадянина;

- мають однакові методи діяльності: проведення перевірок, отримання пояснень, витребування й аналіз документів, використання експертних оцінок тощо.

Основна відмінність контролю від нагляду полягає в тому, що контроль переслідує не тільки досягнення законності та правопорядку, але й забезпечення ефективності та доцільності. Натомість метою нагляду є точне і неухильне виконання законів, яке не супроводжується оцінкою доцільності прийнятих актів і скоєних дій. Під час здійснення нагляду неможливо втручання державного органу в діяльність об'єкта нагляду, тобто в розвідувальну діяльність органу розвідки. «Не можна стверджувати, що нагляд не цікавиться результатами, що виникають у піднаглядних відносинах. У процесі нагляду відбувається спостереження за реалізацією прав у суб'єктивному сенсі. Особливо чітко це простежується у проведенні прокурорського та судового нагляду. У процесі проведення нагляду, на відміну від контролю, існує можливість оцінки відповідності діяльності керованого об'єкта певним вимогам норм із наявністю суворих юридичних санкцій за їх невиконання. Із цього випливає, що нагляд як функція управління має виняткову юридичну природу і сутність, тоді як контроль може здійснюватися і за інших, не юридичних підстав" [10].

Виходячи з цього, можна визначити співвідношення контролю і нагляду як частину і ціле, коли нагляд є облеженим контролем, а основні відмінності можна звести до такого:

- органи нагляду здійснюють свої функції та повноваження щодо тих суб'єктів, які їм організаційно не підпорядковані; органи контролю - переважно щодо організаційно підлеглих і в деяких випадках щодо не підпорядкованих об'єктів;

- у процесі контролю можуть застосовуватися заходи дисциплінарного впливу щодо винних осіб, а у процесі нагляду - заходи як адміністративного впливу, так і політичної відповідальності;

- органи контролю здійснюють перевірку різних сторін діяльності підконтрольних об'єктів, а органи нагляду перевіряють дотримання спеціальних правил [10; 11$]$.

3 огляду на відмінності між контролем $і$ наглядом можна констатувати, що поняття контролю є більш широким, ніж поняття нагляду. Водночас органи, що здійснюють державний контроль, наділені більш широкими повноваженняли, ніж наглядові органи. I все ж «у юридичній науці дотепер немає чіткого тлумачення $і є$ єиного погляду на місие і роль контролю і нагляду в державному регулюючому механізмі (курсив наш - В.П.), що ускладнюе правозастосування у цій сфері діяльності держави. А причиною відсутності наукової однаковості 3 питання співвідношення контролю і нагляду можна назвати багатоаспектність досліджуваних понять, зіставлення яких призводить до не цілком коректних висновків про 
їх співвідношення, а також відсутність у чинному законодавстві визначеності в питанні правового змісту зазначених понять» [10].

Цілком погоджуючись із цим висловлюванням і користуючись здійсненим аналізом законодавства деяких країн стосовно державного нагляду за діяльністю розвідки, можна зробити такі висновки:

1) законодавці дуже стисло і неповно визначають правовими приписами питання державного нагляду за діяльністю своїх органів зовнішньої розвідки;

2) в українських нормативно-правових актах про розвідку, крім констатації того, що генеральна прокуратура та визначені нею прокурори здійснюють нагляд, доцільно розкрити зміст і предмет нагляду, його форми, методи тощо;

3) бажано у вітчизняному законодавстві у конкретних статтях 3 питань нагляду вказувати на необхідність обов'язкової реєстрації в Міністерстві юстиції України відомчих нормативно-правових актів з грифом обмеженого доступу, якщо в останніх йдеться про легітимне обмеження конституційних прав і свобод людини та громадянина.

\section{Jimepamypa}

1. Беляев В.П. Контроль и надзор как формы юридической деятельности : автореф. дис. ... док. юрид. наук : 12.00.01. Саратов, 2006. 55 с. URL: http://law.edu.ru/book/book.asp?bookID=1227777.

2. Конституция Республики Беларусь 1994 г. (с изменениями и дополнениями, принятыми на республиканских референдумах 24 ноября 1996 г. и 17 октября 2004 г.). URL: president.gov.by/ru/constitution ru/.

3. О Службе разведки Грузии : Закон Грузии от 27 апреля 2010 г. № 2984-вс (контрольный текст по состоянию на 22 февраля 2019 г.). URL: https://matsne.gov.ge/ $\mathrm{ru} /$ document/view/92248? publication $=12$.

4. Оразведывательной деятельности:Закон Грузии от 27 апреля 2010 г. № 2983-вс. URL: https://matsne.gov.ge/ $\mathrm{ru} /$ document/download/ 92242/1/ru/pdf.

5. О внешней разведке : Закон Республики Казахстан от 22 мая 2010 г. № 277-IV. URL: http:// ru.government.kz/docs/z100000277_20110106 1.htm.

6. О службах безопасности : Закон Эстонской Республики от 20 декабря 2000 г. № 974 (в редакции от 19 декабря 2007 г.). URL: http://estonia.news-city.info/ docs/sistemsw/dok_iegffb.htm.

7. О внешней разведке : Федеральный Закон Российской Федерации от 10 января 1996 г., № 5-ФЗ. URL: http://www.lawrussia.ru/.

8. О вопросах внешней разведки : Указ Президента Республики Беларусь от 25 марта 2003 г. № 116. URL: http://pravo.levonevsky.org/.

9. Об органах государственной безопасности Республики Беларусь : Закон Республики Беларусь от 10 июля 2012 г. № 390-3. URL: http://www.kgb.by/ru/ zakon390-3/.

10. Погодина Н.А., Карелин К.В. Соотношение контроля и надзора в российской правовой системe. URL: http://www.justicemaker.ru/view-article. php?id $=25 \& \operatorname{art}=3387$.

11. Государственный надзор: понятие, виды, характеристика. URL: http://www.e-reading.club/ chapter.php/.

\section{Анотація}

Прощаєв В. В. Конституційне забезпечення державного нагляду за діяльністю зовнішньої розвідки: порівняльно-правовий аналіз. - Стаття.

У статті 3 позицій юридичної компаративістики шляхом порівняння законодавства провідних країн світу визначено особливості конституційного забезпечення державного нагляду за діяльністю розвідувальних органів. Обгрунтовано, що державний нагляд $\epsilon$ виключною компетенцією органів прокуратури, межі повноважень яких детально прописано правовими нормами в законах про прокуратуру. Ці повноваження не можуть перевищувати межі, визначені конституційними положеннями про функціонування в державі органів прокуратури. 3 наукових позицій досліджено співвідношення контролю і нагляду за діяльністю розвідувальних органів, показано ознаки загального та відмінного між ними. Основна відмінність контролю від нагляду полягає в тому, що контроль переслідує не тільки досягнення законності та правопорядку, але й забезпечення ефективності та доцільності. Натомість метою нагляду є точне і неухильне виконання законів, яке не супроводжується оцінкою доцільності прийнятих актів і скоєних дій. Розглянуто напрями наглядової діяльності прокуратури у сфері державного управління розвідувальними структурами, а також форми реагування представників прокуратури у разі порушення законності керівним складом і співробітниками розвідки. Визначено сутність державного нагляду за діяльністю розвідки, яка полягає в забезпеченні законності та правопорядку шляхом виявлення й усунення порушень закону з боку співробітників розвідувальних органів, а також у їх попередженні. Зміст нагляду становить заснована на законі діяльність спеціально уповноважених суб'єктів - органів прокуратури в особі генерального прокурора та визначених ним прокурорів, спрямована на попередження, виявлення та припинення порушень законів з метою забезпечення верховенства закону, конституційних прав і свобод громадян та охоронюваних законом інтересів суспільства і держави. Зазначено, що в українських нормативно-правових актах про розвідку, крім констатації того, що генеральна прокуратура та визначені нею прокурори здійснюють нагляд, доцільно розкрити зміст і предмет нагляду, його форми, методи тощо.

Ключові слова: порівняльний аналіз, зовнішня розвідка, розвідувальні органи, розвідувальна діяльність, державний нагляд, прокурорський нагляд.

\section{Summary}

Proshayev $V . V$. The constitutional provision of state supervision of foreign intelligence activities: a comparative legal analysis. - Article.

In the article, from the standpoint of legal comparative studies, by comparing the legislation of the leading countries of the world, the features of the constitutional provision of state supervision over the activities of intelligence agencies are defined. It has been substantiated that state supervision is the exclusive competence of the prosecution authorities, the boundaries of powers of which are spelled out in detail by the legal norms in the laws on the prosecutor's office. These powers may not exceed the limits established by the constitutional provisions on the functioning in the state of the prosecution authorities. From the scientific point of view, the ratio of control and supervision over the activities of intelligence agencies has been investigated, and signs of the general and the different between them are shown. The main difference between supervisory control is that the control 
pursues not only the achievement of law and order, but also the maintenance of efficiency and expediency. Instead, the purpose of supervision is the precise and consistent implementation of laws, which is not accompanied by an assessment of the appropriateness of the acts and actions taken. The directions of supervisory activity of the prosecutor's office in the sphere of state management of intelligence structures, as well as the forms of reaction of representatives of the prosecutor's office in cases of violations of legality by the leadership and intelligence personnel are considered. The essence of state supervision over the activity of intelligence, which is to ensure law and order by identifying and eliminating violations of the law by the employees of intelligence agencies, as well as their prevention, is determined. The content of supervi- sion is based on the law of the activities of specially authorized entities - the prosecutor's office in the person of the Prosecutor General and prosecutors appointed by him, which is aimed at preventing, detecting and terminating violations of laws in order to ensure the rule of law, constitutional rights and freedoms of citizens and law-protected public interests. and the state. It is noted that in Ukrainian regulatory acts on intelligence, in addition to stating that the general prosecutor's office and the prosecutors defined by it exercise supervision, it is advisable to disclose the content and subject of supervision, its forms, methods, and the like.

Key words: comparative analysis, foreign intelligence, intelligence agencies, intelligence activities, state supervision, prosecution supervision. 